\title{
The Value, Challenges and Transformation Paths of Discourse Affinity of College Ideological and Political Course in the New Era
}

\author{
Mao Ling ${ }^{1,}$, , Wang Wentao ${ }^{2, b^{*}}$ \\ ${ }^{1}$ College of Marxism, Guangdong Polytechnic of Industry and Commerce, No. 963, North Guangzhou Avenue, \\ Guangzhou, Guangdong Province, China, 510990 \\ ${ }^{2}$ School of Mechanical and Electrical Engineering, Guangzhou City Polytechnic, No. 284 Guangyuanzhong Road, \\ Guangzhou, Guangdong, China, 510405 \\ amonlinger@126.com \\ $b^{*}$ wwt@gcp.edu.cn
}

ABSTRACT

The discourse affinity serves as an essential component of the affinity ecosystem of ideological and political education. In the new era, the discourse affinity of ideological and political course in colleges and universities faces multifarious challenges, such as profound changes in the discourse context, differences in discourse mechanism between educators and the educated, spatial and temporal fragmentation in the discourse field, and conflicts in the discourse paradigms. This paper aims to make the discourse of ideological and political course "genial" by attempting to build a discourse system of "Great Ideological and Political Education". Besides, it also makes ideological and political discourse "compatible" by adopting effective discourse communication strategies. Localized narrative paradigm of discourse is used to produce the "synergy" of the discourse of ideological and political course, so as to continuously improve the affinity and relevance of college ideological and political course.

Keywords: new era, ideological and political course, discourse affinity, challenges, transformation.

\section{INTRODUCTION}

At the symposium for teachers of ideological and political theory course, General Secretary Xi Jinping stressed the importance of promoting reform and innovation in ideological and political theory course and persistently enhancing the ideological level, theoretical property, affinity and relevance of ideological and political theory course. As the key course to implement the fundamental task of fostering virtue through education and the main position of ideological work and socialist core values in colleges and universities, how to realize and maintain its affinity is both a proposition to be explored by the theory of ideological and political education and a realistic problem to be solved during the practice of ideological and political education.

\section{THE VALUE OF DISCOURSE AFFINITY IN COLLEGE IDEOLOGICAL AND POLITICAL COURSE}

\subsection{The Discourse Turn in Ideological and Political Education}

Heidegger states in On the Way to Language that "language alone makes it possible for man to be that kind of organism as a human being ${ }^{[1]}$." Indeed, in all ages, the way in which mankind knows, transforms and owns the world must rely on language, "who associates the mind, feelings and soul of man with communication, exchange and expression, and enlightens his life, freedom and essence [2, 3]". Ideological and political education is "a kind of activity that applies discourse to reflect the persuasive power of theory, with the use of discourse for communication, exchange, understanding and acceptance, so as to achieve the purpose of education [3]", In essence, this process of activity is a flow process of the discourse of ideological and political education. Therefore, the "linguistic turn" provides a new rationale and paradigm for theoretical and practical research on ideological and political education.

\subsection{The Practical Significance of Enhancing the Discourse Affinity of Ideological and Political Course in the New Era}

Discourse acts as the basic carrier of educational content and an important tool for teacher-student interaction during the process of ideological and political education. From the educators' point of view, ideological and political education requires a rich discourse world in order to realize the cognitive, emotional, attitudinal and value contents to be conveyed; and from the perspective of the educated, the growth of an individual's life can 
only be accomplished through language feeling and experience. It can be seen that discourse carries the important mission of dialogue, understanding and meaning-making between educators and the educated in the process of ideological and political education.

The discourse affinity serves as an essential component of the affinity ecosystem of ideological and political education, and the discourse quality directly affects and determines the realization of the effectiveness of ideological and political education. On the strength of the sustainable development of globalization and Internet technology in the new era, the discourse context of ideological and political education in colleges and universities faces many changes, where the choice of discourse content, the expression of discourse mode, the mechanism of discourse acceptance, and the paradigm of discourse transmission all present new directions and qualities with the arrival of the new era. As the main field of ideological and political education, how the discourse of ideological and political theory course not only follows the pace of the times, the general trend of development, and the social reality, but also fully demonstrates the vitality, appeal, leadership and acceptability of the discourse of ideological and political theory courses is a realistic proposition that needs to be explored urgently in the field of ideological and political education in the new era. Once the discourse of ideological and political courses lacks due affinity, ideological and political education will inevitably fall into the state of "voiceless" and "failure", the effectiveness and relevance of ideological and political education will also be greatly reduced.

\section{CHALLENGES TO THE DISCOURSE AFFINITY OF COLLEGE IDEOLOGICAL AND POLITICAL COURSE IN THE NEW ERA}

Since entering the new era, tensions have emerged between the educational logic and the realistic logic of college ideological and political courses, and the enhancement of their discourse affinity has faced the following challenges.

\subsection{The Change of Discourse Content of College Ideological and Political Courses in the New Era}

We are now at the historical intersection of the great changes unprecedently seen in a century in the world and our endeavor to achieve "two centenary goals". With the completion of a moderately prosperous society, China is in a new era of great national rejuvenation, comprehensive development and profound changes in various fields. Vivid social practices of all sorts provide a constant stream of fresh materials for the discourse of ideological and political course, while also posing a realistic challenge to its theoretical and practical discourse to synchronize with the new era: how to vividly integrate the uncertainty of globalization, the historical ups and downs of China, the magnificent times and the rich and varied social changes into classroom teaching; and how to explore the daily scenes of the extremely contemporary, theoretical and social discourse content by expressing an ordinary, textured picture of the world.

\subsection{Expression Conflicts in the Discourse Subject of College Ideological and Political Course in the New Era}

Due to the differences in age, life experience and cultural thought, there are inevitable discrepancy, contradictions and even conflicts in the discourse selection, expression and acceptance mechanisms between educators and the educated, which are especially obvious in the new era. For one thing, educators have the natural right of discourse and are usually in the dominant position in the classroom; for another, the "self-generated" and "decentered" characteristics of the network field in the new era make the educated increasingly aware of their right of discourse and ownership" [4]. Educators who ignore the individuality of the times when the way of discourse of the educated tends to be self and equal, and rely only on discourse authority and discourse indoctrination without respecting the receptiveness of the educated, will find it hard to make the educated accept and understand the meaning and value conveyed behind their discourse successfully. In the discourse field where the educators and the educated meet, if the difference in expression between the two sides in the discourse mechanism cannot be bridged, it is difficult for the educators to achieve the discourse leadership and effective transmission to the educated in the discourse field.

\subsection{Immediate Fragmentation of the Discourse Field of College Ideological and Political Course in the New Era}

With the advent of the mobile Internet era, the consistency of space-time is completely shattered, and the specific physical space under the new technology support can be greatly broken. The original functional meaning of space gradually disappears. There is an overlap of time and multi-layered space, and the spatial diffusion comes to the fore. It can be said that the arrival of new technologies on the Internet has break the synchronization and integrity of the discourse field of educators and the educated in the traditional classroom. With the breakthrough of the physical space of the classroom, the possibility that the educated, though in the classroom, have their ears, eyes, hearts and brains adsorbed by the mobile phone is greatly enhanced, resulting in the discourse field of ideological and political theory classes being shielded to a certain extent. The occurrence and realization of ideological and political education discourse in the new era needs to compete and occupy the initiative of discourse with many discrete virtual spaces under the new technical support. By 
integrating the fragmented discourse field, it shall let the educated return and focus on the real discourse field of the ideological and political course, in order to ensure that the discourse of ideological and political course is genuinely absorbed.

\subsection{Differences in the Paradigms of Discourse Communication of College Ideological and Political Course in the New Era}

From the perspective of the nature of the discipline, the scientific, systematic, value-based and practical nature of Marxist theory has given the ideological and political course a dual paradigm of theoretical and practical discourse, and the communication paradigms of the two are different from each other. The theoretical discourse needs to express the origin of theory and the depth of thought, which is inevitably abstract and hollow, while the practical discourse always has a periodconnected concreteness and vividness, which is inevitably too one-sided and not condensed enough. However, the two are interdependent and complementary. The traditional theoretical discourses such as Marxist beliefs, communist ideals, patriotism, mass line, etc. have to be inherited and carried forward in the practical discourse; likewise, if the theoretical discourse does not pay attention to the real situation, and grasp the reality of the individual, it may turn into an empty sermon detached from the actual thought and life.

In addition, from the perspective of the functional attributes of the discourse, the discourse of the ideological and political course represents the unity of a monolithic social value-driven discourse and a pluralistic individual value-guided discourse. The discourse of ideological and political course requires a macro discourse paradigm of social ideology at the national and social levels, so as to ensure the dominant discourse of socialist core value system; besides, the discourse of ideological and political course shall not ignore the micro real life and individual value needs of the target audience.

Therefore, we shall explore how to integrate the differences between the discourse communication paradigms of ideological and political courses, and continuously expand the degree of discourse consensus between educators and the educated, so as to realize the value consensus of ideological and political education.

4. TRANSFORMATION PATHS TO ENHANCE THE DISCOURSE AFFINITY OF COLLEGE IDEOLOGICAL AND POLITICAL COURSE IN THE NEW ERA

We are expected to deal with the realistic challenges of the reform of the discourse content of college ideological and political in the new era, the differences in the discourse expression, the immediate fragmentation of discourse field and the conflict of communication paradigms. We may start from the most literal level of "affinity" and ponder whether the discourse of ideological and political course can be "genial" or "compatible", and whether it can form a "synergy". In this paper, we will discuss the path to improve the discourse affinity of college ideological and political course from the perspective of this "synergy".

\subsection{Constructing the Discourse System of "Great Ideological and Political Education" with Vitality to Realize the "Genial" Discourse of Ideological and Political Course}

"Geniality" should be the primary temperament and goal of the discourse in the ideological and political course. "Geniality" can be understood as the educated feel both close and intimate to the content and manner of discourse provided by the educators in the ideological and political course. General Secretary Xi stressed at the National Committee of the Chinese People's Political Consultative Conference in the Medical and Health Sector, Education Session: "Ideological and political course should be taught not only in the classroom, but also in social life. [5]" It reveals that how to build a discourse system of "Great Ideological and Political Education" with vitality is the direction we can follow.

We shall first of all build a discourse system of "Great Ideological and Political Education" from the discourse content. This discourse system connects history and reality, bridges the domestic and international, involves political science, philosophy, law, economics, sociology, psychology and other subjects, covering economic, political, cultural, social and ecological fields, etc. Such a discourse system is rich in content, and its rich generalist color may provide a broader and more comprehensive cognitive framework for the educated, thus demonstrating the inherent vitality and infectious power of the discourse of ideological and political course.

We shall then build the discourse system of "Great Ideological and Political Education" from the discourse form of ideological and political course. The discourse system of "Great Ideological and Political Education" not only includes the existing textbook discourse, theoretical discourse and other textual discourse and multifarious historical materials and cases, but also requires the timely inclusion of various vivid social practice discourse. China is currently at the historical intersection of the great changes unprecedently seen in a century in the world and our endeavor to achieve "two centenary goals". China is increasingly approaching the center of the world stage, and the chapters of the times that hundreds of millions of people have written and are writing are vivid discourse materials of "Great Ideological and Political Education". The most current theoretical ideas and the most grounded real-life cases are integrated into the discourse system, content and manner of discourse of the ideological and political course, vividly and imaginatively showing the changes of the times and theoretical thinking. For example, the vivid cases of national fighting against the COVID-19 are integrated into the teaching materials, classrooms and society in time, so as to teach young students the "Great Ideological and Political Education" 
of fighting against the outbreak. By integrating the background of the two "great changes" into the theoretical explanation and narration of the ideological and political course, the historical origin and practical basis of the "Four-Sphere Confidence" can be more effectively and convincingly explained.

The "genial" discourse of the ideological and political course should be supported by a discourse system adapted to the changing context of the times, fully integrating the dimensions of the times and reality, and constructing a reliable source for the discourse content of "Great Ideological and Political Education". Besides, the "genial" discourse should be supported by a discourse system adapted to the audience, and we are expected to reconstruct the discourse expression of "Great Ideological and Political Education" by virtue of Internet thinking and audience thought. It shows the internal vitality and development logic of the discourse of college ideological and political theory courses in the new era, displays the attraction, appeal and persuasion of ideological and political education, and creates a humane "great classroom" of ideological and political education with soul and depth, so as to create preconditions for improving the pertinence and effectiveness of ideological and political theory courses.

\subsection{Adopting the Discourse Strategy of Effective Communication to Realize the "Compatible" Discourse of Ideological and Political Course}

From the perspective of communication science, the discourse communication of ideological and political course needs to go through a process of information exchange from discourse generation, discourse transmission, discourse reception then to discourse understanding. Only from unilateral transmission to bilateral dialogue, only from the pre-setting to the focus of generation of goals, can this process of language flow and dialogue be completed, so as to achieve discourse acceptance and exchange. We regard this process as the "compatibility" of the discourse of ideological and political course.

The "compatible" discourse of the ideological and political course is first and foremost based on the "I-am" form of the educated. Under the new technical support, educated people face more opportunities to stray from the discourse field of the ideological and political course. Only when the discourse content of the ideological and political course fully release the charm and light of ideology and theory, concern the real life and world of the educated, and remove the confusion of the educated, can the educated place themselves in the discourse field of the ideological and political course and return to the identity of the students in the classroom.

In the second place, "I-think" occupies an important position in the discourse of ideological and political course. Educated people do not passively accept and obey the educators' discourse. They are subjects of action and experience with their own uniqueness and individuality, and they will construct their own discourse world and discourse style to express their own understanding and thinking for life according to their specific and subtle life experiences.

Finally, "I-speak" is the key to the dissemination of discourse in ideological and political course. "I-speak" is the behavior of educated people who begin to respond positively to the teaching discourse, which is a continuation of "I-am" and "I-think". At this point, educated students break through the traditional silent subject and disembodied subject in the quiet listening mode, and no longer attach themselves to the educators' discourse system; they can fully feel the space of "I-canspeak" in the classroom, and turn from a passive object to a subject claiming their own discourse rights, showing the subjectivity of their existence; and the positive transmission of the educator's dialogue is thus smooth and effective.

We use holistic process thinking to examine and optimize the discourse communication process of ideological and political theory course, so that educators and the educated can be mutually on the scene visibly and audibly. Even if there is a temporary break in the field, educators can adjust the discourse communication strategy in time, so as to form a dynamic interaction process of communication and integration of harmonious and inseparable relationship, and constantly contribute to the exchange of discourse and understanding and acceptance of both sides. This will gradually reach the "compatibility" of the discourse of college ideological and political course, and lay a solid foundation for the final realization of the discourse affinity of ideological and political course.

\subsection{Creating a Localized Discourse Narrative Paradigm to Realize the "Synergy" of the Discourse of Ideological and Political Course}

The discourse of college ideological and political course cannot "be stuffed with the reasoning theory and concepts, making theory a dogma irrelevant to practice" [6]. Xi, the general secretary of the National Committee of the Chinese People's Political Consultative Conference (CPPCC), visited the medical and health sector and the education committee and stressed that "we should put forward new ideas and build new theories from the practice of reform and development in China, and strive to build an academic system and discourse system with Chinese characteristics, Chinese style and Chinese manner" [7]. The way of telling the Chinese story facilitates the spread of the Chinese voice. Whenever General Secretary Xi Jinping quotes scriptures and tells the stories of outstanding Chinese traditions and people around him, we can easily understand and empathize with them and then leave a deep and unforgettable impression. Therefore, I believe that this narrative paradigm derived from localized discourse is a path worth trying and 
learning from in the process of enhancing the discourse affinity of ideological and political course.

The teaching video of Zhou Rongfang, a teacher of ideological and political course in Zhengzhou University, told the story of Jiao Yulu of Lankao County in class on Bilibili.com has received more than 100 million views. She chose the story of Jiao Yulu, the Party Secretary of Lankao County, to tell to the students of Zhengzhou University. The affinity of the discourse emerges in an unhurried way, and the students are thus attracted and they take the initiative to enter the discourse field created by the teacher, experience the personality charm of the characters in the story in the narration of the teacher's true feelings, and think about the value and meaning behind the story. Jiao Yulu is honest in performing his official duties and assiduous in government affairs with serving the people, and his dedication spirit of giving his best until his heart ceases is slowly entered into the heart of the educated through dialogue. They are therefore guided to consciously practice the responsibilities of the younger generation in the new era.

The activity of ideological and political education is originally a kind of artificial existence and is a practical activity in which educators and the educated "coexist". The localized narrative paradigm, as the discourse of ideological and political course, reflects the reality and presence of ideological and political education, where the "here-being" of the educators and the "there-being" of the educated create a "common context" through the story narrative. It derives emotional interaction in the discourse, and reach a kind of sharing and understanding of the meaning behind the discourse, thus leading to the "copresence" of both parties. This "co-presence" dissolves the differences in discourse fields and discourse conflicts between educators and the educated, and ultimately realizes the effectiveness of the ideological and political course.

\section{CONCLUSION}

Enhancing the affinity of college ideological and political course is an enduring topic in the study of ideological and political education, and a topic that will always be studied and updated. In the new era, the discourse affinity of college ideological and political course is facing many new problems, which is both a challenge and an opportunity for innovation and development to enhance its discourse affinity. From the connotation of the concept of "affinity", to enhance the affinity of discourse, it is necessary to gradually realize the "geniality", "compatibility" and "synergy" of ideological and political course. This is not only the essential requirement of realizing the discourse affinity of ideological and political course, but also the realistic goal of improving the affinity of ideological and political course, which can be used as both a way and a standard. The gradual improvement of the discourse affinity of the ideological and political course facilitates the ideological, theoretical and targeted realization of ideological and political theory course.

\section{PROJECT FUND}

This paper is the research on the discourse affinity and its enhancement path of college ideological and political course in the new era (2020JKDY065), and the research results of the project of Guangdong Provincial Education Science Thirteenth Five-Year Plan 2020 (2020GXJK515) and Guangzhou Education Science Plan 2021 (202113693).

\section{REFERENCES}

[1] Deng Xiaomang. On Heidegger's Poetic Philosophy of Language. Journal of Nanjing University (Philosophy - Humanities - Social Sciences) [J]. 2021, 58(01): 21-9+161-2.

[2] $\mathrm{Xu}$ Jie. The change of the paradigm of ideological and political education discourse in universities in the micro era. Educational Exploration [J]. 2017, 04): 75-7.

[3] Ruan Tao. Paradigm shift of ideological and political education discourse in the era of self-media. Journal of the Party School of Tianjin Committee of the CPC [J]. 2018, 20(02): 66-71.

[4] Li Yehong. Research on the construction of teaching discourse system of college ideological and political theory courses in new era. The Party Building and Ideological Education in Schools [J]. 2021, 11): 27-9.

[5] Shen Zhuanghai. We should make good use of the "great ideological and political course": Reflections and explorations. Ideological and Political Education Research [J]. 2021, 37(03): 26-30.

[6] Liu Sanbao, Xie Chengyu. The logical reasoning and realization path of ideological and political theory courses in colleges and universities to cultivate the new generation of the times. Party building and ideological education in schools [J]. 2021, 05): 47-50. 